\title{
Recommendation of Choline Inclusion in Lambs' Diet
}

\author{
Martínez-Aispuro, José A. ${ }^{1}$; Sánchez-Torres María T. ${ }^{1 *}$; Figueroa-Velasco, José L. ${ }^{1}$; Cordero-Mora, José L. ${ }^{1}$ \\ ${ }^{1}$ Colegio de Postgraduados, Campus Montecillo, Programa de Ganadería. Texcoco Estado de México, México. \\ CP. 56230 . \\ * Corresponding author: teresa@colpos.mx
}

\begin{abstract}
Objective: To establish an inclusion recommendation for choline (herbal or synthetic) in fattening lambs' diet based on productive performance and blood metabolites.

Design/Methodology/Approach: A literature review was carried out of herbal and synthetic choline supplementation in the diet of fattening lambs.

Results: The addition of protected choline chloride (50\% purity) in the lamb's diet should be less than 2.5 $\mathrm{g} / \mathrm{kg}$ DM in order not to cause a detrimental effect on the productive performance. On the other hand, the inclusion of herbal choline in lambs' diet should be greater than $6 \mathrm{~g} / \mathrm{kg}$ DM to have positive effects on body gain and feed conversion.

Study Limitations/Implications: It is necessary to establish the requirement for choline in fattening lambs because studies where choline is supplemented show that the contribution of conventional ingredients is insufficient.

Findings/Conclusions: The inclusion of herbal ( $6 \mathrm{~g} / \mathrm{kg} \mathrm{DM})$ and synthetic (2.5 g/kg DM) choline in lambs' diet improves body weight gain and modifies energy metabolites.
\end{abstract}

Keywords: choline chloride, phosphatidylcholine, herbal, sheep, synthetic.

Citation: Martínez-Aispuro, José A., Sánchez-Torres María T., FigueroaVelasco, José L., Cordero-Mora, José L. Recommendation of Choline Inclusion in Lambs' Diet. Agro Productividad, 14(\#). https://doi.org/ 10.32854/agrop.v14i6.1951

Editor in Chief: Dr. Jorge Cadena Iñiguez

Estimated publication date: July 2021

This work is licensed under a Creative Commons Attribution-NonCommercial 4.0 International license (c) (1) \$

\section{INTRODUCTION}

Choline is a water-soluble vitamin of the B complex that is required in lambs' nutrition, and its metabolites are important for the synthesis of proteins, phospholipids, acetylcholine, and the metabolism of hepatic fats (NRC, 2007). The choline obtained from the feed ingested is degraded significantly in the rumen and very little escapes ruminal degradation (Baldi and Pinotti, 2006). Although there are sources of protected choline (PC) available, they are generally not included in the diet because the requirement has not been established clearly, though its inclusion in the diet can improve the productive performance (NRC, 2007).

Protected choline chloride (PCC) from ruminal degradation obtained synthetically has been the source of choline most frequently evaluated for small ruminants (Bryant et al., 1999; Godinez-Cruz et al., 2015; Habeeb et al., 2017), and lower doses of 2.5 g/ $\mathrm{kg}$ of DM showed beneficial effects in the productive performance of lambs (Li et al., 2015).

Another alternative to add choline to the diet is the use of plants with high content of choline conjugates that resist ruminal degradation. The results from studies show that the addition of herbal choline in the lamb's diet (Godinez-Cruz et al., 2015; Martínez-Aispuro et al., 2019) and in the production ewe's milk (Alba et al., 2020) make production more efficient. One of the advantages of the inclusion of herbal choline is that it contains primarily phosphatidylcholine, which enters directly to the animal's metabolism (Godinez-Cruz et al., 2015; Crosby et al., 2017). 
Therefore, the objective of this literature review is to attempt to establish a recommendation of choline inclusion (synthetic or herbal) in fattening lambs' diets based on productive performance and blood metabolites.

\section{Choline in ruminants}

Choline is a water-soluble vitamin from the B complex that must be synthesized endogenously, unlike other water-soluble vitamins. Choline is an essential nutrient for mammals, especially when methionine and folic acid are limited in the diet (Zeisel et al., 1991; Zeisel and Holmes-McNary, 2001). Choline, methionine, betaine, folic acid and vitamin B12 in the diet contribute to the choline requirements.

Choline occupies a key position between the energy and protein metabolism in mammals. Choline per se plays an important role in the metabolism of lipids, particularly in lipid transport, as lipotropic agent, optimizing the balance between fat retained and fat metabolized by the liver (Baldi and Pinotti, 2006). Choline is a critical component for the synthesis of phospholipids (phosphatidylcholine), which has structural functions in the biological membranes and in the use of lipids by the tissues. Choline is also a component of neurotransmitters (acetylcholine), supporting the structural integrity and the signaling functions in cell membranes (Zeisel and Holmes-McNary, 2001). Choline is an important source of unstable methyl groups for the biosynthesis of other methyl compounds via betaine for methylation reactions, as in the cases of the formation of methionine from homocysteine and creatine from guanidinoacetic acid (NRC, 2007). Based on this last function, choline and methionine are exchangeable, as sources of methyl groups (Pinotti, 2012). The choline demand as methyl donor is probably the main factor that determines the speed with which choline induces metabolic inefficiency (Zeisel et al., 1991).

In ruminants, choline from the diet is thoroughly degraded in the rumen, which is why its availability is low, while the demand from methyl compounds is particularly high, and it is likely that choline and methionine are scarce, as well as the other sources of methyl groups (Pinotti, 2012).

From the point of view of animal nutrition, the relatively high sources of choline are soybean, soybean meal, rapeseed meal, fish meal and dry yeast, although its bioavailability is considered "moderate". This is why it is thought that choline from the diet contributes insignificantly to the body reserve in adult ruminants (Pinotti et al., 2002). Studies in sheep show that $76 \%$ of the choline injected in the rumen is degraded as methane, while 15\% was accumulated as trimethylamine. Under such conditions, less than $10 \%$ of the choline escapes the degradation from incorporation, such as phosphatidylcholine, in the structural membranes of ciliated protozoa (Neill et al., 1979).

The data reviewed in this document are consistent with these assumptions and support the need of supplementation with choline protected from ruminal degradation for fattening lambs, which can improve the balance of the metabolism of methyl groups and the state of other nutrients. 


\section{Protected choline chloride (PCC) in lambs}

Several feedstuffs used in ruminant nutrition contain choline, but this natural choline is degraded rapidly in the rumen, so it must be offered as choline protected from ruminal degradation in ruminant species (Kawas et al., 2020). In this review, the use of choline chloride is one of the main sources used to supplement choline within the diet of ruminants, although choline chloride is not well absorbed in the intestine and most of it is degraded in the rumen (Sharma and Erdman, 1989). Therefore, the incorporation of this choline must be protected from ruminal degradation, thus increasing the availability for intestinal absorption (Baldi and Pinotti, 2006). Other PCC problems are that commercial products differ in their choline content and degradability in the rumen (Kung et al., 2003; Brusemeister and Sudekum, 2006); in addition, it is only absorbed 61\% of the choline chloride that reaches the duodenum (Veth et al., 2016).

The evaluations with PCC products have improved milk production in cows (Sales et al., 2010; Jayaprakash et al., 2016), weight gain in beef cattle (Pinotti et al., 2009), and feed conversion and meat quality in fattening goats (Habeeb et al., 2017; Tu et al., 2020). Li et al. (2015), when supplementing different PCC concentrations at 50\% purity (0.25, 0.50 and $0.75 \%$ ) in fattening lambs, observed a quadratic response in gain weight and feed conversion concluding that the best level was $2.5 \mathrm{~g} / \mathrm{kg}$ of PCC, since with the levels of 0.50 and $0.75 \%$ the productive response had a detrimental effect. Bryant et al. (1999) observed that the ADG was reduced when using 2.5 and $5 \mathrm{~g} / \mathrm{kg}$ DM of PCC (25\% purity) in the lamb's diet, but a similar response to the control treatment was obtained with 10 $\mathrm{g} / \mathrm{kg}$ DM of PCC. Kawas et al. (2020) evaluated different levels (0, 0.1, 0.2 and 0.3\%) of a product with a concentration of 25\% PCC in fattening lambs' diet. The addition of PCC in the diet was not associated with the feed intake, weight gain, feed conversion, body weight, and carcass yield although more dorsal fat was obtained with higher levels of RPC.

\section{Herbal choline in lambs}

There is a commercial herbal additive (herbal choline) that contains phosphatidylcholine which shows natural resistance to ruminal degradation in sheep with the potential of replacing the PCC products (Godinez-Cruz et al., 2015; Crosby et al., 2017). Studies show that the inclusion of herbal choline in ruminants can improve milk production and general health (Gutiérrez et al., 2019; Mendoza et al., 2020).

Martínez-Aispuro et al. (2019), when evaluating three levels of herbal choline (3, 6 and $9 \mathrm{~g} / \mathrm{kg}$ MS) in the diet, observed that the ADG and feed conversion improved with a linear response when increasing the additive, although a better productive response was observed when adding 6-9 g/kg of herbal choline. In another study (Rodríguez-Guerrero et al., 2018), the inclusion of $4 \mathrm{~g} / \mathrm{kg} \mathrm{DM}$ of herbal choline in the diet did not affect the growth response of fattening lambs, although it did affect the feed digestibility and the weight of the carcass. In an attempt to increase the availability of methyl compounds, these same authors (Rodríguez-Guerrero et al., 2018) combined herbal choline with protected methionine but they did not find any effect on the growth variables. 
Herbal choline is a product based on herbs that concentrates only $16 \mathrm{~g} / \mathrm{kg}$ of total choline conjugates, and in addition it contains other metabolites that could modify the growth performance and ruminal fermentation (Martínez-Aispuro et al., 2019; Mendoza et al., 2020). Crosby et al. (2017) observed that supplementation of ewes with $4 \mathrm{~g}$ /day of herbal choline from 30 days before and until 30 days after the birth increased the lamb's birth weight, the milk production, and the content of oleic fatty acid in the milk. Roque-Jiménez et al. (2020) hypothesized that the active compounds of herbal choline have epigenetic properties that could impact the fetal development and growth of the offspring of ewes supplemented during the entire gestation with $4 \mathrm{~g} /$ day; however, they only observed increments in milk production, quality of colostrum, and milk.

Godinez-Cruz et al. (2015) attempted to compare the synthetic and herbal choline in fattening lambs without clear results, since when supplementing with $4 \mathrm{~g} / \mathrm{kg}$ DM from both sources in sheep they found null effects on the productive response.

\section{Effect of choline in lambs' health}

Studies have shown that phosphatidylcholine and choline could stimulate the immune response (Lewis et al., 2015). Supplementation with herbal choline (5 g/day) in sheep in the transition period improved milk production (persistence in the peak of lactation and production) and general health (Alba et al., 2020). Goats growing under heat stress showed an increase in globulins when supplementing with PCC (Habeeb et al., 2017). The general health status in response to the intake of herbal choline was reflected in the increase of globulins (Martínez-Aispuro et al., 2019; Alba et al., 2020) and enzymes related to the immune system (Alba et al., 2020).

\section{Effect of supplementation with protected choline on lambs' metabolism}

The increments in the concentration of choline in blood confirm that the supplementation of herbal choline is effective to incorporate this metabolite into the organism of sheep (Crosby et al., 2017; Martínez-Aispuro et al., 2019) and the PCC in goats (Habeeb et al., 2017). In humans, the levels of choline in plasma were reduced through the restriction of choline in the diet (Zeisel et al., 1991). Meanwhile, experiments in rats showed that phosphatidylcholine in the diet was effective to increase the level of choline in blood (Lewis et al., 2015).

Studies in lambs reported that the inclusion of PCC or herbal choline in the diet increased the concentrations of non-esterified fatty acids (Bryant et al., 1999; RodríguezGuerrero et al., 2018; Guo et al., 2020), cholesterol (Rodríguez-Guerrero et al., 2018), glucose, (Rodríguez-Guerrero et al., 2018; Martínez-Aispuro et al., 2019), low density lipoproteins (Li et al., 2015; Martínez-Aispuro et al., 2019; Guo et al., 2020), and reduced high density lipoproteins ( $\mathrm{Li}$ et al., 2015) and triglycerides (Rodríguez-Guerrero et al., 2018; Kawas et al., 2020).

Choline could act by altering the intracellular signaling of the energy metabolism, and supplementation with choline to insulin resistance mice reduced the use of 
glucose for the synthesis of fatty acids and triglycerides, and increased muscular glycogen (Taylor et al., 2017). Choline is associated with the receptors activated by peroxisome proliferators that regulate adipogenesis and lipogenesis (Yu et al., 2003), as well as adiponectin, which performs an important role in the regulation of metabolism of fatty acids and glucose. The change in the concentration of phosphatidylcholine in the organism can influence the biological activity and expression of genes that regulate the production of high and low density lipoproteins (Cole et al., 2012). In addition, choline in the liver through phosphatidylcholine is necessary for packaging and export triglycerides in the very low density lipoproteins (Noga and Vance, 2003).

In experiments with lambs, Li et al. (2015) showed that the expression of several genes related to lipogenesis varied between the levels of PCC. However, the variables of the carcass and fat depots did not change in response to the levels of PCC (Bryant et al., 1999; Li et al., 2015) despite the lipotropic effect of choline (Piepenbrink and Overton, 2003) and the fact that the oxidized form of choline (betaine) reduces fat depots in other species (Eklund et al., 2005).

Although herbal choline has a lower concentration of choline byproducts, it can offer similar results to PCC because herbal choline contains phosphatidylcholine (GodinezCruz et al., 2015; Crosby et al., 2017). Phosphatidylcholine is the main phospholipid of ruminants, essential for the absorption and transport of lipids, maintenance of the cell membrane structures, cellular signaling, and lipoprotein synthesis (Zeisel and HolmesMcNary, 2001). The metabolic path of phosphatidylcholine in the organism differs from that of free choline, since phosphatidylcholine requires less energy expense and does not require several metabolic processes to be available for the cells (Fagone and Jackowski, 2013).

\section{CONCLUSION}

The inclusion of herbal ( $\left.6 \mathrm{~g} \mathrm{~kg}^{-1} \mathrm{DM}\right)$ and synthetic $\left(2.5 \mathrm{~g} \mathrm{~kg}^{-1} \mathrm{DM}\right)$ choline in lambs' diet improves body weight gain. The inclusion of choline in the diet modifies the energy metabolites, which in turn make more efficient the productive response. Protected synthetic or herbal choline is resistant to rumen degradation, since this metabolite is present in the animal's organism.

\section{REFERENCES}

Alba, D.F., Favaretto, J.A., Marcon, H., Saldanha, T.F., Leal, K.W., Campigoto, G., Souzad, C.F., Baldisserad, M.D., Bianchid, A.E., Vedovatto, M., and Da Silva, A.S. (2020). Vegetable biocholine supplementation in pre-and postpartum Lacaune sheep: Effects on animal health, milk production and quality. Small Ruminant Research: The Journal of the International Goat Association. 190:106165. Doi: 10.1016/j.smallrumres.2020.106165

Baldi, A., \& Pinotti, L. (2006). Choline metabolism in high-producing dairy cows: Metabolic and nutritional basis. Canadian Journal of Animal Science. 86 (2) : pp.207-212. Doi: 10.4141/A05-061

Brusemeister, F., \& Sudekum, K.H. (2006). Rumen-protected choline for dairy cows: the in situ evaluation of a commercial source and literature evaluation of effects on performance and interactions between methionine and choline metabolism. Animal Research. 55 (2) :pp.93-104. Doi :10.1051/animres:2006002 
Bryant, T.C., Rivera, J.D., Galyean, M.L., Duff, G.C., Hallford, D.M., \& Montgomery, T.H. (1999). Effects of dietary level of ruminally protected choline on performance and carcass characteristics of finishing beef steers and on growth and serum metabolites in lambs. Journal of Animal Science. 77 (11) :pp.2893-2903. doi: doi.org/10.2527/1999.77112893x

Cole, L.K., Vance, J.E., \& Vance, D.E. (2012). Phosphatidylcholine biosynthesis and lipoprotein metabolism. Biochimica et Biophysica Acta. 1821 (5): pp.754-761. Doi: 10.1016/j.bbalip.2011.09.009

Crosby, M., Mendoza-Martinez, G.D., Relling, A., Vazquez, V.A., Lee-Rangel, H.A., Martinez, J.A., \& Oviedo, M. (2017). Influence of supplemental choline on milk yield, fatty acid profile, and postpartum weight changes in suckling ewes. Journal of Dairy Science 100(Suppl. 2):p.125.

Eklund, M., Bauer, E., Wamatu, J., \& Mosenthin, R. (2005). Potential nutritional and physiological functions of betaine in livestock. Nutrition Research Reviews. 18 (1) : pp.31-48. Doi: 10.1079/NRR200493

Fagone, P., \& Jackowski, S. (2013). Phosphatidylcholine and the CDP-choline cycle. Biochimica et Biophysica Acta. 1831 (3) :pp.523532. Doi: 10.1016/j.bbalip.2012.09.009

Godinez-Cruz, J., Cifuentes-López, O., Cayetano, J., Lee-Rangel, H., Mendoza, G., Vázquez, A., \& Roque, A. (2015). Effect of choline inclusion on lamb performance and meat characteristics. Journal of Animal Science. 93(Suppl. 3): p.766.

Guo, C., Xue, Y., Yin, Y., Sun, D., Xuan, H., Liu, J., \& Mao, S. (2020). The effect of glycerol or rumen-protected choline chloride on rumen fermentation and blood metabolome in pregnant ewes suffering from negative energy balance. Animal Feed Science and Technology. 268 (114594). Doi: 10.1016/j.anifeedsci.2020.114594

Gutiérrez, A., Gutiérrez, A., Sánchez, C., \& Mendoza, G.D. (2019). Effect of including herbal choline in the diet of a dairy herd; a multiyear evaluation. Emirates Journal of Food and Agriculture.31(6): pp.477-481. doi : 10.9755/ejfa.2019.v31.i6.1971

Habeeb, A.A.M., Gad, A.E., Atta, M.A.A., \& Abdel-Hafez, M.A.M. (2017). Evaluation of rumen-protected choline additive to diet on productive performance of male Zaraibi growing goats during hot summer season in Egypt. Tropical Animal Health and Production. 49 (6) : pp.1107-1115. Doi: 10.1007/s11250-017-1292-x

Jayaprakash, G., Sathiyabarathi, M., Robert, M.A., \& Tamilmani, T. (2016). Rumen-protected choline: A significance effect on dairy cattle nutrition. Veterinary World. 9 (8): pp.837-841. Doi: 10.14202/vetworld.2016.837-841

Kawas, J.R., Garcia-Mazcorro, J.F., Fimbres-Durazo, H., \& Ortega-Cerrilla, M.E. (2020). Effects of rumen-protected choline on growth performance, carcass characteristics and blood lipid metabolites of feedlot lambs. Animals. 10 (9): p.1580. doi: 10.3390/ani10091580

Kung, L., Putnam, D. E., \& Garrett, J. E. (2003). Comparison of commercially available rumen-stable choline products. Journal of Dairy Science. 86(Suppl 1):p.275.

Lewis, E.D., Richard, C., Goruk, S., Dellschaft, N.S., Curtis, J.M., Jacobs, R.L., \& Field, C.J. (2015). The form of choline in the maternal diet affects immune development in suckled rat offspring. The Journal of Nutrition. 146 (4): pp.823-830. Doi: $10.3945 /$ jn. 115.225888

Li, H., Wang, H., Yu, L., Wang, M., Liu, S., Sun, L., \& Chen, Q. (2015). Effects of supplementation of rumen-protected choline on growth performance, meat quality and gene expression in longissimus dorsi muscle of lambs. Archives of Animal Nutrition. 69 (5): pp.40-350. Doi: 10.1080/1745039X.2015.1073001

Martínez-Aispuro, J.A., Mendoza, G.D., Cordero-Mora, J.L., Ayala-Monter, M.A., Sánchez-Torres, M.T., Figueroa-Velasco, J.L., Vázquez-Silva, G., \& Gloria-Trujillo, A. (2019). Evaluation of an herbal choline feed plant additive in lamb feedlot rations. Revista Brasileira de Zootecnia. 48: e20190020. Pp.1-7. Doi: 10.1590/rbz4820190020

Mendoza, G.D., Oviedo, M.F., Pinos, J.M., Lee-Rangel, H.A., Vázquez, A., Flores, R., Perez, F., Roque, A., \& Cifuentes, O. (2020). Milk production in dairy cows supplemented with herbal choline and methionine. Revista de la Facultad de Ciencias Agrarias UNCuyo. 52 (1): pp.332-343.

Neill, A.R., Grime, D.W., Snoswell, A.M., Northrop, A.J., Lindsay, D.B., \& Dawson, R.M.C. (1979). The low availability of dietary choline for the nutrition of the sheep. The Biochemical Journal, 180 (3): pp.559-565. Doi: 10.1042/bj1800559 
Noga, A.A., \& Vance, D.E. (2003). A gender-specific role for phosphatidylethanolamine N-methyltransferase-derived phosphatidylcholine in the regulation of plasma high density and very low density lipoproteins in mice. Journal of Biological Chemistry. 278 (4):pp.21851-21859. Doi: 10.1074/jbc.M301982200

National Research Council (NRC). 2012. Nutrient Requirements of Swine (11th Ed.). National Academy Press, Washington, DC. Pp 208-239.

Piepenbrink, M.S., \& Overton, T.R. (2003). Liver metabolism and production of cows fed increasing amounts of rumenprotected choline during the periparturient period. Journal of Dairy Science. 86 (5): pp.1722-1733. Doi: 10.3168/jds.S00220302(03)73758-8

Pinotti, L., Baldi, A., \& Dell'Orto, V. (2003). Comparative mammalian choline metabolism with emphasis on the high-yielding dairy cow. Nutrition Research Reviews. 15 (2): pp.315-332. Doi: 10.1079/NRR200247

Pinotti, L., Paltanin, C., Campagnoli, A., Cavassini, P., \& Dell'Orto, V. (2009). Rumen protected choline supplementation in beef cattle: effect on growth performance. Italian Journal of Animal Science. 8 (2): pp.322-324.

Pinotti, L. (2012). Vitamin-like supplementation in dairy ruminants: the case of choline. In: Milk Production-An Up-to-Date Overview of Animal Nutrition, Management and Health. Chaiyabutr, N. (First Ed). IntechOpen, Rijeka, Croatia. Pp. 65-86.

Rodríguez-Guerrero, V., Lizarazo, A.C., Ferraro, S., Suárez, N., Miranda, L.A., \& Mendoza, G.D. (2018). Effect of herbal choline and rumen-protected methionine on lamb performance and blood metabolites. South African Journal of Animal Science. 48 (3): pp.427-434. Doi: 10.4314/sajas.v48i3.3

Roque-Jiménez, J.A., Mendoza-Martínez, G.D., Vázquez-Valladolid, A., Guerrero-González, M.L., Flores-Ramírez, R., PinosRodriguez, J.M., Loor J.J., Relling, A.E., and \& Lee-Rangel, H.A. (2020). Supplemental herbal choline increases 5-hmC DNA on whole blood from pregnant ewes and offspring. Animals. 10 (8):p.1277. doi: 10.3390/ani10081277

Sales, J., Homolka, P., \& Koukolova, V. (2010). Effect of dietary rumen-protected choline on milk production of dairy cows: A meta-analysis. Journal of Dairy Science. 93 (8): pp.3746-3754. Doi: 10.3168/jds.2010-3106

Sharma, B.K., \& Erdman, R.A. (1989). In Vitro Degradation of choline from selected foodstuffs and choline supplements. Journal of Dairy Science. 72 (10): pp.2772-2776. Doi: 10.3168/jds.S0022-0302(89)79421-2

Taylor, A., Schenkel, L. C., Yokich, M., \& Bakovic, M. (2017). Adaptations to excess choline in insulin resistant and Pcyt2 deficient skeletal muscle. Biochemistry and Cell Biology. 95 (2):pp.223-231. Doi: 10.1139/bcb-2016-0105

Tu, Y.L., Zhang, K., Bai, Y.F., Gao, L.P., \& Hong, W. (2020). Effects of rumen-protected choline supplied at different dietary energy levels on growth performance and meat quality of fattening goats. Journal of Animal and Feed Sciences. 29 (3): pp.234-240. Doi: $10.22358 / j a f s / 127693 / 2020$

Veth, M.J., Artegoitia, V.M., Campagna, S.R., Lapierre, H., Harte, F., \& Girard, C.L. (2016). Choline absorption and evaluation of bioavailability markers when supplementing choline to lactating dairy cows. Journal of Dairy Science. 99 (12) : pp.97329744. Doi: 10.3168/jds.2016-11382

Yu, S., Matsusue, K., Kashireddy, P., Cao, W.Q., Yeldandi, V., Yeldandi, A.V., Rao, M.S., Gonzalez, F.J., \& Reddy, J.K. (2003). Adipocytespecific gene expression and adipogenic steatosis in the mouse liver due to peroxisome proliferator-activated receptor $\gamma 1$ (PPARy1) overexpression. Journal of Biological Chemistry. 278 (1):pp.498-505. Doi: 10.1074/jbc.M210062200

Zeisel, S.H., Da Costa, K.A., Franklin, P.D., Alexander, E.A., Lamont, J.T., Sheard, N. F., \& Beiser, A. (1991). Choline, an essential nutrient for humans. The FASEB Journal. 5 (7): pp.2093-2098. Doi: 10.1096/fasebj.5.7.2010061

Zeisel, S.H., \& Holmes-McNary, M. (2001). Choline. In: Handbook of Vitamins. Rucker, R.B., Suttie, J.W., \& McCormick, D.B. (Third Ed). New York, USA. Pp. 513-528. 